\title{
Influence of landscape context on the abundance of native bee pollinators in tomato crops in Central Brazil
}

\author{
Edivani V. Franceschinelli ${ }^{1}$ ( $\cdot$ Marcos A. S. Elias $^{2} \cdot$ Leonardo L. Bergamini $^{3}$ • \\ Carlos M. Silva-Neto ${ }^{4} \cdot$ Edison R. Sujii $^{5}$
}

Received: 9 February 2017 / Accepted: 20 July 2017 / Published online: 24 July 2017

(c) Springer International Publishing AG 2017

\begin{abstract}
Evidence shows that pollinator abundance has declined and, consequently, so has their services, which has possible negative impacts on ecosystem functioning. The goal of this study was to evaluate the influence of landscape context at multiple spatial scales on the abundance of bee pollinators of tomato crops in Brazil. Pollinator abundance was obtained from tomato crops grown in a conventional system in the Cerrado region. Around each tomato field circular buffers of $0.75,1,1.5,2$, and $3 \mathrm{~km}$ radius were defined. Inside each buffer the landscapes were manually classified into native and non-native cover and, the proportion of native vegetation, the relative largest patch size, and the distance of the nearest native vegetation to each field were calculated. Pollinator species were categorized into five groups: Exomalopsis, Centris, Bombus/Eulaema, Halictidae, and all buzz pollinators combined (Buzzers). The results showed that the landscape context influenced
\end{abstract}

Electronic supplementary material The online version of this article (doi:10.1007/s10841-017-0015-y) contains supplementary material, which is available to authorized users.

Edivani V. Franceschinelli

edivanif@gmail.com

1 Departamento de Botânica, Universidade Federal de Goiás, Goiânia, GO 74690-900, Brazil

2 Departamento de Ecologia, Instituto de Ciências Biológicas, Universidade de Brasília, Brasília, DF 70910-900, Brazil

3 Departamento de Ecologia, Instituto de Ciências Biológicas, Universidade Federal de Goiás, Goiânia, GO 74690-900, Brazil

4 Instituto Federal de Educação, Ciência e Tecnologia de Goiás, Cidade de Goiás, GO 76600-000, Brazil

5 Recursos Genéticos e Biotecnologia, Embrapa, Av. W5 Norte, Brasília, DF 70770-917, Brazil the abundance of the five groups of tomato pollinators. Bees with a smaller body size, such as Exomalopsis spp., responded at smaller scales, while bees with a larger body size, such as the Centris and Bombus/Eulaema groups, responded at larger scales. The abundance of all pollinator groups increased with native vegetation cover. Most groups showed higher abundances in landscapes with similarsize fragments. The results reinforce the recommendation for maintaining natural habitats around crop areas, even if fragmented, for the conservation of the tomato pollinator assemblage. These findings are valuable for planning landscape management in the studied area to improve bee conservation, ecosystem services, and food production.

Keywords Buzzers - Cerrado - Ecosystem service · Exomalopsis $\cdot$ Fragmentation $\cdot$ Habitat loss $\cdot$ Halictidae

\section{Introduction}

Pollinator loss, especially bees, has been reported in different parts of the world (Potts et al. 2010, 2015; Goulson et al. 2015). This is worrying because animals pollinate $78 \%$ of the angiosperms in the temperate regions and $94 \%$ in the tropics (Ollerton et al. 2011). Consequently, pollinator loss could cause changes in the diversity and functioning of natural ecosystems (Allen-Wardell et al. 1998). Bees are especially important for many cultivated plants (Klein et al. 2007; Silva-Neto et al. 2013; IPBES 2016), and several studies have shown a relationship between pollinator loss and reduction in crop productivity (Kevan 1977; Ricketts et al. 2004; Potts et al. 2015).

The decline in bee populations is due to a combination of different causes, such as pesticide use (Whitehorn et al. 2012), diseases and parasites (Fürst et al. 2014), and 
habitat loss and fragmentation (Kearns et al. 1998). Habitat loss and fragmentation are probably the most important factors for insect pollinator communities, including bees, wasps, flies, beetles, butterflies, and moths (Kruess and Tscharntke 1994; Steffan-Dewenter et al. 2002; SteffanDewenter 2003; Steffan-Dewenter and Kuhn 2003). The negative effects of habitat loss on insect pollinators may include reduction in the availability of food resources and lack of nesting sites, which lead to reduced landscape carrying capacity (Harris and Johnson 2004). Better conserved landscapes generally have greater richness and abundance of bee species, and consequently should provide more reliable pollination of crop plants (Steffan-Dewenter et al. 2002; Viana et al. 2012). Other features, such as the proximity of native vegetation fragments (Ricketts et al. 2008), high-quality habitats (Kennedy et al. 2013), and the size of native fragments (Aizen and Feinsinger 1994) have similar effects.

Responses of bee species to anthropogenic changes at the landscape scale are still poorly understood (Winfree 2013; De Palma et al. 2015). This is due to a considerable variation in life history traits among bee taxa (Michener 2001), such as the degree of specialization in the use of floral resources, the degree of sociality, in dispersal ability, and the type of substrate used for nesting (Goulson et al. 2005; Greenleaf et al. 2007; Morandin et al. 2007; Ricketts et al. 2008). In European agriculture landscapes, this is most strongly influenced by flight season duration and foraging range, but also by niche breadth, reproductive strategy and phenology (De Palma at al. 2015). In addition to differences in dispersal ability (Greenleaf et al. 2007), this variation leads to different responses of different bee species to landscape properties (Greenleaf and Kremen 2006; Winfree and Kremen 2009). Changes in landscape features should be assessed at multiple scales in order to detect these differences (Steffan-Dewenter et al. 2002; Mckenzie et al. 2013). Studies developed in tropical areas have also revealed the importance of native vegetation on the abundance and diversity of pollinators in cultivated areas (Boreux et al. 2013; Romero and Quezada-Euan 2013; Landaverde-González et al. 2017). In Mexico, bee species diversity increases with the proportion of forest cover surrounding chili fields (Landaverde-González et al. 2017). In Brazil, coffee production was higher in crops that were close to native vegetation compared to others that were further (De Marco and Coelho 2004). Similar results were observed in Indonesia (Klein et al. 2003a, b) and in Costa Rica (Ricketts et al. 2004).

This study analyzes the effects of landscape features at different scales on the abundance of bee taxa groups, using tomato (Solanum lycopersicum L.) crops as the study system. Tomato is the vegetable with the largest production in Brazil, with over 4 million tons produced in 2013 (IBGE
2015). Despite being a self-pollinated species, pollinators increase the pollen load on the stigma of tomato flowers, which leads to greater fruit production (Greenleaf and Kremen 2006; Silva-Neto et al. 2013). Several bee species pollinate tomato flowers by buzz pollination. Moving their thorax muscles, they vibrate the poricidal anthers removing the pollen grains (Fontes and Silva 2002). In previous observations of bees in tomato crops in Brazil (Nunes-Silva et al. 2010), only native species perform buzz pollination (Table S1). Until now, no study has shown the effects of the landscape context on the abundance or richness of a functional group of pollinators such as buzzing bees, especially in tropical regions. The objective of this study was to evaluate the influence of landscape features, such as native vegetation proportion, on the abundance of buzzing bees that pollinate tomato flowers. In this study, only bees able to vibrate tomato flower anthers to expel their pollen grains (hereafter referred to as buzzers) were analyzed. Because we preferred not to collect all the buzzers observed visiting the tomato flowers during the experiment, it was not possible to identify them during their visits to the flowers. The buzzers were categorized into five groups based on their taxonomical and ecological relationships. Here, the main goal is to answer the following questions: (1) What effects do the proportion of native vegetation in areas surrounding tomato plantations have on the abundance of bees at different scales? (2) Do tomato crops located closer to natural vegetation remnants have greater abundance of buzzer bees? (3) Do different groups of bee species show different responses to the level of fragmentation, proportion, and proximity to natural vegetation?

\section{Materials and methods}

\section{Location and period of collection}

This study was conducted in the state of Goiás, Brazil, in 10 tomato fields during 2010 (between August 7th and October 17th) and 14 tomato fields during 2011 (between May 21st and September 27th) (Fig. 1). The sampled municipalities have a landscape with forest and Cerrado fragments embedded in a matrix composed mainly of pasture and arable land, where tomatoes, cucumbers, cabbages, corn, beans, and oranges are cultivated. The natural areas in the study system are small irregularly shaped patches that often form narrow corridors of vegetation next to streams and water bodies.

The landscapes surrounding the fields were classified from a Landsat 5-TM satellite image (dated October 10, 2005), with spatial resolution of $30 \times 30 \mathrm{~m}$, georeferenced based on topographic maps of the Brazilian Institute of Geography and Statistics-IBGE, on a scale of 1: 50,000. 


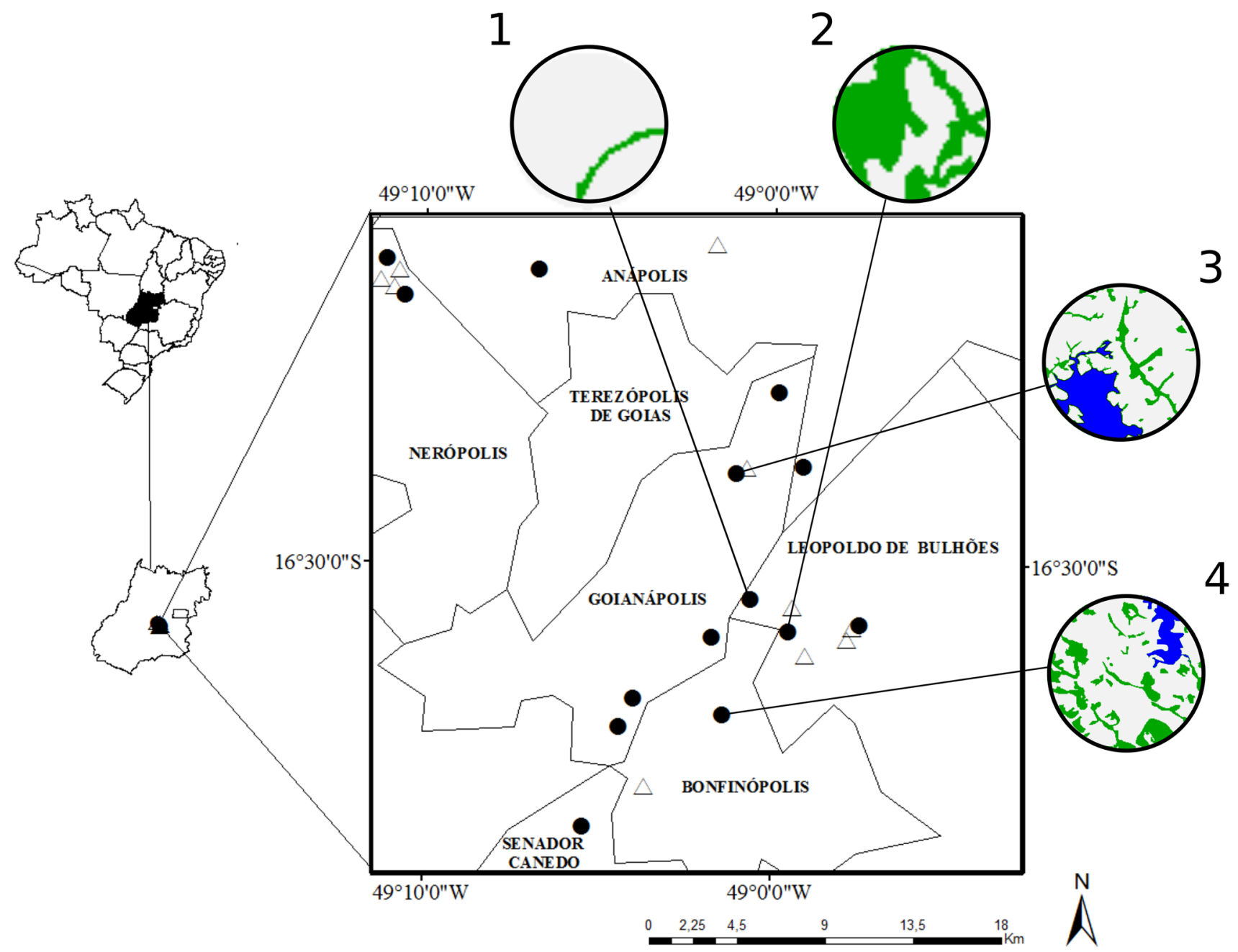

Fig. 1 Location of the 10 tomato crops collected in 2010 and of the 14 crops sampled in 2011 in the state of Goiás, Brazil. Open triangles correspond to 2010 and filled circles correspond to the year 2011. Landscape callouts with examples for the metrics are presented beside the map. Landscapes 1 and 2 have no fragmentation (All native vegetation in the landscape is contiguous) rLPS, with $100 \%$ of the native vegetation concentrated in a single fragment (relative Larges Patch Size) $=1$, but differ on the proportion of native veg-

An image from 2005 was used because it was available and native vegetation loss was very low (less than $1 \%$ ) within the municipalities of studied areas from 2002 to 2010 (MMA/IBAMA/PNUD 2009; Rocha et al. 2010; MMA/ IBAMA 2011a, b). The coordinates were obtained in UTM, Datum SAD 1984, and the spectral bands TM3, TM4, and TM5 were used. The native vegetation fragments (Cerrado and native forests) were delimited by manual classification. Since it is expected that different bee species may respond to landscape context at different scales, we used a multiscale approach. Buffers (circles) of 0.75, 1, 1.5, 2, and 3 kilometers $(\mathrm{km})$ radius were defined, by taking the center of each sample point (tomato field) and using the images etation (Landscape $1=4 \%$, Landscape $2=55 \%$ ). Landscapes 3 and 4 have both similar proportions of native vegetation (Landscape $3=28 \%$, Landscape $4=27 \%$ ), but differ in the degree of fragmentation, with Landscape 3 having the most native vegetation found in the largest patch (blue patch) and high rLPS (0.74) and Landscape 4 with a smaller largest patch (blue patch) and more fragmented native vegetation $(\mathrm{rLPS}=0.26)$

classified by the method described above. Buffers with radius smaller than $0.5 \mathrm{~km}$ often had no native vegetation, because the tomato fields themselves were very large. So, the circles are delimited from $0.75 \mathrm{~km}$. Geo referencing and classification procedures were performed in the remote sensing image processing system ArcGIS 9.3 (ESRI Inc.).

We assessed landscape context using two measures that describe both the composition and configuration of native vegetation in the landscape within the delimited area for each of the five buffers: (1) proportion of native vegetation in the landscape (prop); and (2) relative size of the largest fragment (rLPS) (Bascompte and Sole 1996; Montoya et al. 2010) (Fig. 1). The rLPS is a measure of vegetation 
continuity, ranging from 0 to 1 , where values near 1 indicate landscapes with little fragmentation of the native vegetation. Unlike indices such as patch number and mean patch size, which are highly correlated with the amount of habitat (Fahrig 2003), the rLPS index provides a more direct measure of the degree of fragmentation (Bascompte and Sole 1996). Additionally, we also calculated the distance between each tomato crop and the closest fragment of native vegetation. In order to avoid computing distances to very small fragments, we only considered in this calculation fragments with at least 1 hectare. The values for the proportion of native vegetation in the landscape (prop), relative size of the largest fragment (rLPS) and the distances between the crops and the closest fragment were calculated using the $\mathrm{R}$ software (R Development Core Team 2015), using the packages maptools (Bivand and LewinKoh 2015), rgdal (Bivand et al. 2015), and raster (Hijmans 2015).

\section{Plant description}

Tomato plants have small yellow flowers that are hermaphrodites and form monochasial cymes with 3-12 flowers (Fontes and Silva 2002). The main tomato cultivars studied here were 'Italian' and 'Dominador'. Although these commercial varieties of tomato are self-compatible, their flowers depend on the visit of buzzing bees to improve the quality and quantity of fruits and seeds (McGregor 1976; Silva-Neto et al. 2013; Deprá et al. 2014).

\section{Abundance of floral pollinators}

Bee activity was recorded in each field by two observers to estimate bee abundance. The two observers walked in four rows of about 120 tomato plants in 15-min shifts, counting the number of buzzer visits. A total of $360 \mathrm{~min}$ of observations were done in each field from August to October in 2010 and between 80 and $160 \mathrm{~min}$ in each field from May to September in 2011. Observations were made mainly between 9:00 and 13:00 $\mathrm{h}$ on at least two different days with clear weather and wind speed below $3 \mathrm{~m} / \mathrm{s}$.

In this study, only bees capable of buzz pollination were analyzed. In the studied areas, the species unable to perform buzz pollination (no-buzzer) were small bees that visit tomato flowers inserting their mandibles within the anthers and apparently only rob pollen (Silva-Neto et al. 2016, Table S1). Therefore, careful observations were made to recognize buzzer bees and distinguish them from "nonbuzzer" flower visitors. However, all unidentified species of bee were collected for identification using sweep nets. All bees were pinned and identified to the lowest possible taxonomic level. Bee identifications were carefully carried out in the laboratory of Plant Reproductive Biology at the Federal University of Goiás. All bee identifications were confirmed by Dr. Fernando A. Silveira (Federal University of Minas Gerais) and Dr. Favízia Freitas Oliveira (Federal University of Bahia). The buzzer bees were categorized into five groups based on their taxonomical and ecological relationships due to the uncertainty of field-based identifications (Table 1).

\section{Statistical analysis}

A model selection approach was used to assess whether bee abundance was greater in more preserved landscapes (i.e., landscapes with a greater proportion of native vegetation and greater rLPS index values). By using a model selection approach we were able to test simultaneously the effects of both variables and the scale at which there was the best fit. For each bee species group and landscape scale (buffer radius), Poisson GLMs (Generalized Linear Models) were adjusted with the abundance of bees as the response variable and the proportion of native vegetation, the rLPS, or both variables simultaneously as predictors. In addition to these three models, a model containing only the intercept was adjusted. Therefore, we adjusted 16 different models in each case, being three models for the combinations of predictors in each of the five scales, plus the model with only the intercept. Data from the two

Table 1 Criteria used to group the bee species observed in tomato fields, based on ecological and morphological similarities to reduce fieldbased identifications

\begin{tabular}{ll}
\hline Group & Description \\
\hline $\begin{array}{l}\text { 1. Buzzers } \\
\text { 2. Exomalopsis }\end{array}$ & $\begin{array}{l}\text { All bees of the studied areas able to perform buzz pollination } \\
\text { Bees of the genus Exomalopsis that have similar behavior and morphology and cannot be accurately identified in the field } \\
\text { at species level, but probably play similar roles in tomato pollination }\end{array}$ \\
$\begin{array}{l}\text { Bees of the family Halictidae (with the exception of the genus Dialictus, which is too small to perform buzz pollination in } \\
\text { tomato flowers) that are very similar and hard to differentiate in the field }\end{array}$ \\
$\begin{array}{l}\text { Bees of the genus Centris, which are morphologically different from other tomato flower visitors and are oil collectors } \\
\text { (Michener 2001) }\end{array}$ \\
$\begin{array}{l}\text { 5. Bombus/Eulaema } \\
\text { Bees of the genera Bombus and Eulaema, which have similar body sizes and are the largest visitors to tomato flowers }\end{array}$
\end{tabular}


Table 2 Average, minimum and maximum proportion of native vegetation (Prop) and the relative size of the larger fragment (rLPS) for five buffers around 10 tomato crops in 2010 and 14 crops in 2011 in the state of Goiás

\begin{tabular}{llll}
\hline Radius $(\mathrm{km})$ & Variable & $\begin{array}{l}\text { Mean }(\mathrm{min}-\mathrm{max}) \\
2010\end{array}$ & $\begin{array}{l}\text { Mean }(\mathrm{min}-\mathrm{max}) \\
2011\end{array}$ \\
\hline 0.75 & Proportion & $0.25(0.12-0.55)$ & $0.18(0.04-0.38)$ \\
1 & Proportion & $0.24(0.13-0.41)$ & $0.19(0.03-0.34)$ \\
1.5 & Proportion & $0.22(0.14-0.38)$ & $0.20(0.08-0.35)$ \\
2 & Proportion & $0.22(0.17-0.34)$ & $0.21(0.10-0.36)$ \\
3 & Proportion & $0.24(0.18-0.32)$ & $0.24(0.13-0.32)$ \\
0.75 & rLPS & $0.61(0.30-1.00)$ & $0.68(0.41-1.00)$ \\
1 & rLPS & $0.54(0.22-0.98)$ & $0.61(0.37-0.91)$ \\
1.5 & rLPS & $0.41(0.22-0.70)$ & $0.47(0.15-0.84)$ \\
2 & rLPS & $0.32(0.16-0.50)$ & $0.41(0.22-0.69)$ \\
3 & rLPS & $0.30(0.11-0.64)$ & $0.38(0.13-0.74)$ \\
\hline
\end{tabular}

different years were analyzed separately due to difficulties in model convergence when including the random effect of the years. Since we only make qualitative evaluations of differences between years this does not impair our results or interpretations. Observation times differed between the fields only in 2011, and were thus included in the 2011 models. All adjusted models were then ranked based on their Akaike Information Criterion with correction for finite sample sizes-AICc (Burnham and Anderson 2002), and the model with the smaller AICc value was selected. In this way, each variable was considered in all the different buffers in turn. The scale that provided the better fit, and consequently, the smaller AICc was selected, allowing for a simultaneous test of the effects of the variables and the scale at which they have the greater effect. When the difference between the AICc value of the two models was smaller than 2, an average model for the selected models was computed. Inference was then made by assessing the confidence intervals for the fully averaged coefficients of the selected model(s). A pseudo- $\mathrm{R}^{2}$ measure, following Heinzl and Mittlböck (2003), was computed to assess the fit of the model, along with a chi-squared likelihood-ratio test.

The effects of distance of native vegetation fragments on bee abundance were evaluated using GLMMs (Generalized Linear Mixed Models) with abundance of each bee species group as response variables and distance as predictor. This analysis was done separately because the distance variable is scaled differently from other landscape variables. Visitation rate in bee abundance models was calculated as the number of bees observed per minute, and year was included as a random effect. Random slopes for the effect of distance on response variables were used to estimate the variation between years in observed effects (Zuur et al. 2009). All analyses were performed in $R$ environment ( $R$
Development Core Team 2015) using the packages MuMIn (Bartón 2015) and lme4 (Bates et al. 2015).

\section{Results}

Landscape analysis around sampled tomato fields revealed a wide variation in the proportion of native vegetation (0.03-0.55) and rLPS values (0.11-1.00) across the different buffer scales, providing a suitable contrast for the proposed modeling framework. These values characterize the region as highly disturbed by farming and fragmented native vegetation, and low rLPS values occur mainly at larger scales (Table 2).

A total of 656 visits of bees (buzzers) to tomato flowers were observed, averaging $0.46 \pm 0.43($ mean $\pm S D)$ visits per minute for $3600 \mathrm{~min}$ of observation in ten fields in 2010. In 2011, there were 698 visits, with an average of $0.67 \pm 0.32($ mean $\pm S D)$ visits per minute for $1660 \mathrm{~min}$ in 14 fields. Exomalopsis species were the most frequent in both years studied (Table 3 ).

According to AICc-based model selection procedure, only one of the models relating to bee visitation rate and landscape variables was selected in each year for buzzers, Exomalopsis, and Centris groups (Table 4). For Halictidae group, two models were selected each year, and for Bombus/Eulaema group, two models in 2010 and one model in 2011 were selected (Table 4).

Abundance was positively associated with the landscape variables for all groups in the two years studied, with the only exception being the Bombus/Eulaema group in 2010 (Figs. 2, 3, 4). The abundance of the buzzer groups Exomalopsis and Centris was positively associated with the proportion of native vegetation (Fig. 2a, c), although the scale at which the effect of native vegetation was observed varied between 2010 and 2011 (Table 4). Landscape continuity (rLPS) exerted a negative effect on abundance only in 2010 for the buzzer and Exomalopsis groups (Fig. 2b, d). Landscapes more fragmented presented higher bee abundance. Additional information is available about the best model coefficient estimates in Online Appendices S2-S7.

Table 3 Relative frequency of visits of different bee groups to tomato flowers in 10 tomato crops in 2010 and 14 crops in 2011 in the state of Goiás

\begin{tabular}{lll}
\hline Groups & $\begin{array}{l}\text { Frequency of visits } \\
2010(\%) \mathrm{N}=656\end{array}$ & $\begin{array}{l}\text { Frequency of } \\
\text { visits 2011 }(\%) \\
\mathrm{N}=698\end{array}$ \\
\hline Exomalopsis & 74.2 & 73.8 \\
Halictidae & 10.5 & 16.6 \\
Centris & 11.9 & 7.3 \\
Bombus/ Eulaema & 3.4 & 2.3 \\
\hline
\end{tabular}


Table 4 Descriptors of the models selected to portray the relationship between bee abundance and the predictor percent cover of native vegetation (prop) and relative largest patch size (rlps), for groups of bee species from 10 tomato crops in the year 2010 and in 14 tomato crops in the year 2011 (state of GoiásBrazil)

\begin{tabular}{lllllllll}
\hline Groups & Models & $\mathrm{k}$ & AICc & Delta & Weight & $\mathrm{r}^{2}$ & L. ratio $\chi^{2}$ & $\mathrm{p}$ \\
\hline 2010 & & & & & & & & \\
Buzzers & Prop 2 km +rLps 2 km & 3 & 220.4 & 0.00 & 1.000 & 0.21 & 94.17 & $<0.001$ \\
Exomalopsis & Prop 2 km +rLps 2 km & 3 & 200.9 & 0.00 & 1.000 & 0.32 & 120.49 & $<0.001$ \\
Halictidae & Prop3 km +rLps 3 Km & 3 & 86.60 & 0.00 & 0.457 & 0.19 & 25.16 & $<0.001$ \\
& Prop 3 km & 2 & 87.30 & 0.71 & 0.321 & 0.21 & 20.16 & $<0.001$ \\
Centris & Prop 3 km & 2 & 69.30 & 0.00 & 0.830 & 0.39 & 26.10 & $<0.001$ \\
Bombus/Eulaema & Prop 3 km & 2 & 46.50 & 0.00 & 0.359 & 0.06 & 7.54 & 0.006 \\
& Prop 1.5 km & 2 & 46.70 & 0.24 & 0.193 & 0.04 & 6.30 & 0.012 \\
2011 & & & & & & & & \\
Buzzers & Prop 1 km + Obsv. time & 3 & 155.3 & 0.00 & 0.766 & 0.24 & 38.02 & $<0.001$ \\
Exomalopsis & Prop 1 km + Obsv. time & 3 & 136.2 & 0.00 & 0.863 & 0.20 & 25.52 & $<0.001$ \\
Halictidae & rLps 3 km + Obsv. time & 3 & 125.8 & 0.00 & 0.707 & 0.34 & 52.57 & $<0.001$ \\
& Prop 3 km + rLps & 4 & 127.5 & 1.76 & 0.293 & 0.29 & 54.86 & $<0.001$ \\
& 3 km + Obsv. time & & & & & & & \\
Centris & Prop 2 km + Obsv. time & 3 & 95.80 & 0.00 & 0.770 & 0.23 & 15.86 & $<0.001$ \\
Bombus/Eulaema & rLps 3 km + Obsv. time & 3 & 37.70 & 0.00 & 0.524 & 0.45 & 23.83 & $<0.001$ \\
\hline
\end{tabular}

Delta values are relative difference between the AICc of each model and the AICc of the best model. AIC weights are normalized estimates of the relative likelihood of each model and are used in the model averaging process so better models have a greater contribution in the estimation of the averaged coefficients. Pseudo R-squared values were computed using the equation from Heinzl \& Mittlbock 2003. Likelihoodratio chi-squared tests were used to test if the difference between the deviation of the adjusted model and the deviation of the null model is significant

$k$ number of model parameters, Obsv. time observation time
We found conflicting results between the two years for the Halictidae group (Table 4; Fig. 4c). There was a negative relationship between abundance and the proportion of native vegetation in 2010 and a negative effect of continuity of the landscape on abundance in 2011, with more fragmented landscapes having a greater abundance of Halictidae. Finally, landscape continuity exerted a negative effect on abundance of the Bombus/Eulaema group (Table 4; Fig. 4e) in 2011. The distances from native vegetation were often small (mean $=196 \mathrm{~m}$, range $=10-539 \mathrm{~m}$, Online Appendix S7), and there was no relationship between the distance and any of the response variables (Table 5). This lack of effect was consistent between years, with little variance explained by the year random effect (Table 5).

\section{Discussion}

Landscape context influenced the abundance of the five groups of tomato pollinators. The pattern of abundance presented by the group buzzer, which includes all buzz pollinators, is quite similar to the pattern of Exomalopsis species. This may have been recorded because Exomalopsis species are the most frequent bees that visited tomato flowers in the studied fields, and comprise the most important pollinator group. A recent review of 90 studies that encompassed 785 bee species showed that few common bee species are able to provide most of the pollination services to the studied fields, which supports the importance of identifying these species groups (Kleijn et al. 2015), as proposed in our study.

The fragmentation of native vegetation had a positive effect on the abundance of all pollinator groups, except for the Centris group, in at least one of the study years. These data show that areas with small fragments of similar size have higher bee abundance than areas with a larger fragment. The largest fragments in the study area are mainly gallery forest with a long, straight shape. Gallery forest fragments are commonly crossed by cattle to drink water from streams, mainly during the dry season. In this period, because local farmers usually do not produce or buy cattle forage, cattle may eat leaves of the edge forest (E. V. Franceschinelli, pers. obs.), increasing the edge effect and the forest disturbance especially of long shaped fragments. Other studies carried out in Brazil showed that the abundance and richness of Euglossini bees were not correlated with fragment size but with the size of core areas of the fragments, suggesting that orchid bee conservation requires the preservation of the fragments with the largest possible core pristine areas (Nemésio and Silveira 2010). The long shaped gallery forest present in the study areas may have smaller core pristine areas than the smaller fragments. However, the heterogeneity of the surrounding landscape could mitigate the 

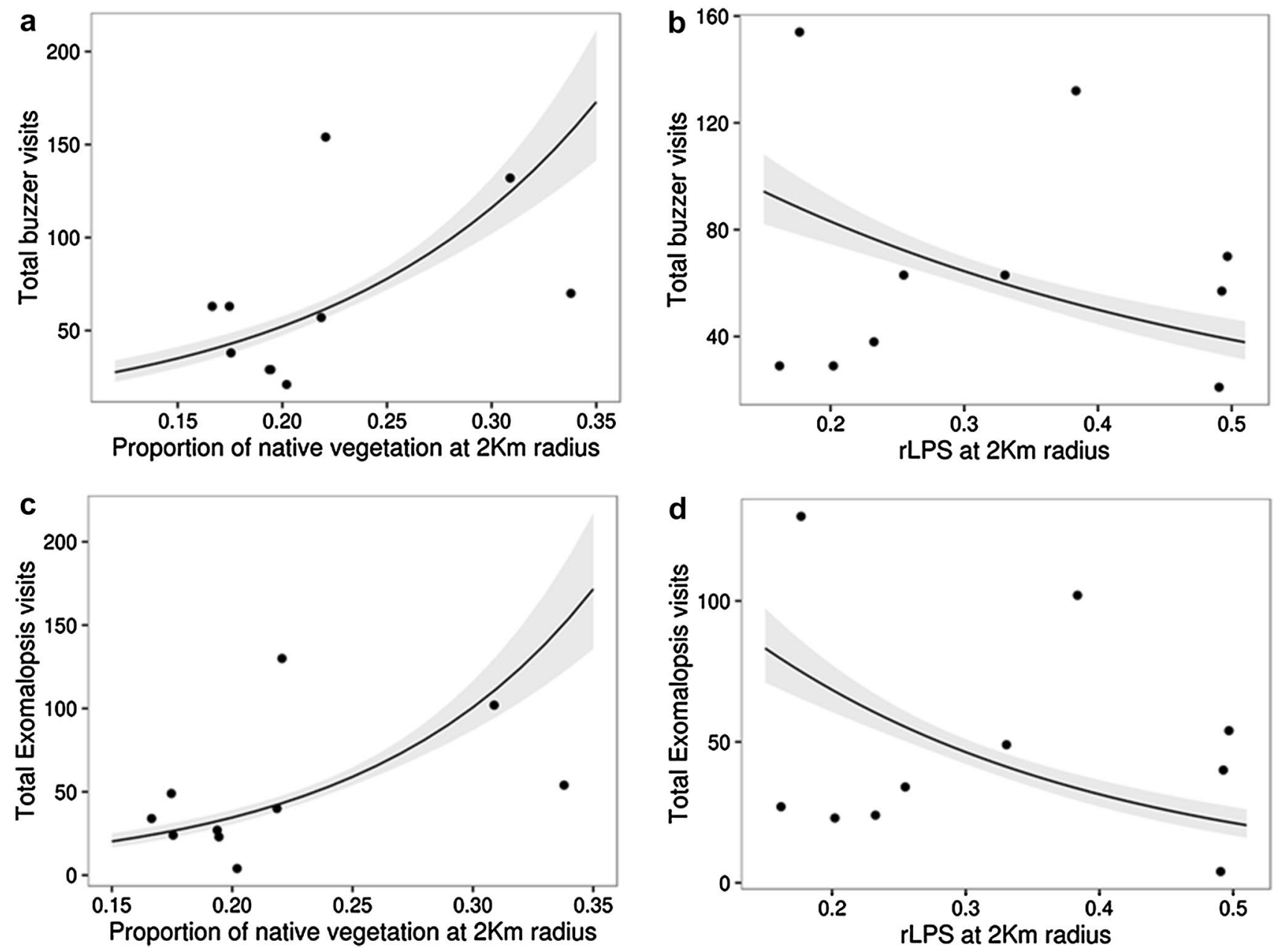

Fig. 2 Some of the relationships observed in the year 2010. We show between parentheses the pseudo- $\mathrm{R}^{2}$ and the $\mathrm{p}$ value of the corresponding model. a Buzzer visits and proportion of native vegetation at $2 \mathrm{~km}$ radius $\left(\mathrm{R}^{2}=0.21, \mathrm{p}<0.001\right)$. b Buzzer visits and rLPS

at $2 \mathrm{~km}$ radius $\left(\mathrm{R}^{2}=0.21, \mathrm{p}<0.001\right)$. $\mathrm{c}$ Exomalopsis visits and proportion of native vegetation at $2 \mathrm{~km}$ radius $\left(\mathrm{R}^{2}=0.32, \mathrm{p}<0.001\right)$. d Exomalopsis visits and rLPS at $2 \mathrm{~km}$ radius $\left(\mathrm{R}^{2}=0.32, \mathrm{p}<0.001\right)$

negative effect of the small size of the pristine core areas of the native fragments favoring the diversity of pollinators as proposed by Rösch et al. (2013) that the more complex landscape tends to show a greater diversity of insects disregarding the size of the fragment. In addition, several fragments of native vegetation distributed in the landscape may offer availability of different types of native habitat (Tscharntke et al. 2002; LandaverdeGonzález 2017), which suggests that the higher abundance of buzzer pollinators in areas with high number of small fragments may be a consequence of habitat heterogeneity. Those results show the importance of conserving pristine areas of every native fragment even if small, because such fragments may be responsible for increasing habitat diversity and may provide critical resources for the maintenance of some species, especially those with high mobility (Tscharntke et al. 2002; Rueda et al. 2013).

Some bees of the Cerrado biome may be naturally adapted to live in open environment, because the Cerrado biome comprises a mosaic of different vegetation physiognomies ranging from forest areas to open fields with herbaceous formation (Oliveira-Filho and Ratter 2002). The vegetation of the studied area became fragmented in the 1940s (Waibel 1948), and the existing bee species of the local community may be those more able to forage or nest in disturbed environments. For example, Eulaema nigrita occurs naturally in pasture and open fields (Tonhasca Jr. et al. 2003; Brosi 2009; Pinto et al. 2015), and their abundance may be higher in fragmented areas (Powell and Powell 1987; Tonhasca Jr. et al. 2003). This and other native species may necessarily feed on flowers of ruderal plant 




Fig. 3 Some of the relationships observed in the year 2011. We show between parentheses the pseudo- $\mathrm{R}^{2}$ and the $\mathrm{p}$ value of the corresponding model. a Buzzer visits and proportion of native vegetation

species or in species that naturally occur in open fields of Cerrado and pastures. In addition, phenological studies of Cerrado vegetation have shown that it is possible to find species blooming throughout the year (Oliveira and Gibbs 2002), which indicate the availability of resources for pollinators in remnant fragments of the native vegetation. This suggests that many pollinator species may be highly vagile, because they must be able to use different resources distributed among different landscape components.

The Exomalopsis group responded at a scale smaller than the Centris and Halictidae groups. The last groups showed greater response variability in both years. A likely explanation for the difference in the scale of response between the Exomalopsis and Centris groups would be the different foraging range among the species, which is influenced by body size (Gathmann and Tscharntke 2002; Greenleaf et al. 2007). Exomalopsis species have close to $9 \mathrm{~mm}$ length and Centris around $17 \mathrm{~mm}$ (Michener 2001). Small bees forage at smaller spatial scales, while larger bees fly at larger spatial scales (up to five $\mathrm{km}$ ) (Osborne et al. 1999; Walther-Hellwig and Frankl 2000; Knight et al. 2005; Lepais et al. 2010). Besides, Exomalopsis spp. may have more independent dispersal ability, given that they nest underground. Pastures are abundant in the area and may provide good nesting substrates for Exomalopsis spp. This difference in response among species can lead to important functional variation (Benjamin et al. 2014); which is an important mechanism for promoting the stability of ecosystem services, such as pollination (Winfree and Kremen 2009).

The Exomalopsis and Centris groups showed consistent responses in the 2 years studied, while the other groups showed different responses in the 2 years. Two factors can

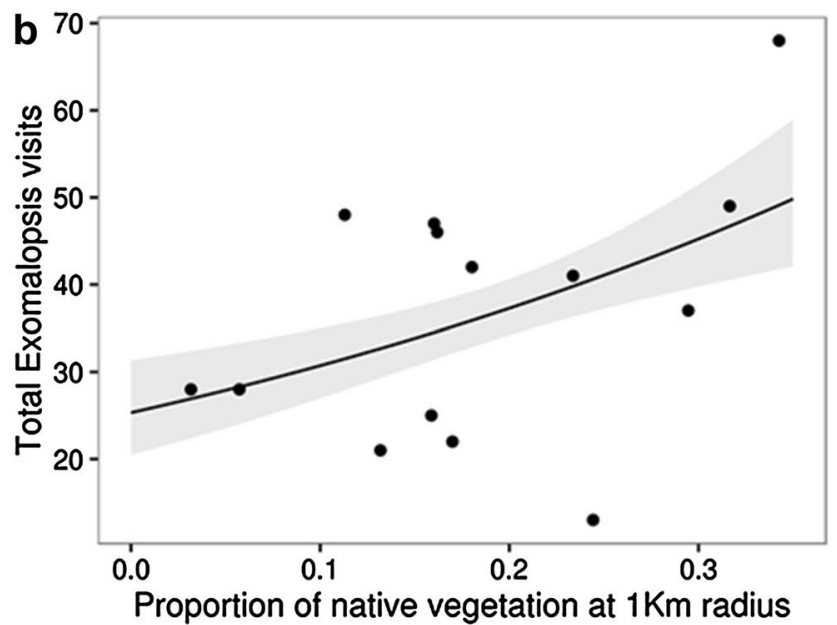

at $1 \mathrm{~km}$ radius $\left(\mathrm{R}^{2}=0.24, \mathrm{p}<0.001\right)$. b Exomalopsis visits and proportion of native vegetation at $1 \mathrm{~km}$ radius $\left(\mathrm{R}^{2}=0.20, \mathrm{p}<0.001\right)$

explain this variation. The first is the presence of temporal fluctuations in environmental conditions or resources that affect the size of Halictidae and Bombus/Eulaema bee populations, because insect populations, especially bees, have pronounced seasonal and spatial fluctuations year to year (e.g., Roubik 2001; Williams et al. 2001). The second factor could be spatial/temporal changes in bee species composition throughout the years. For example, although species of the Halictidae family have great morphological similarity, which hinder field identification at species level, life history attributes have a high variation among species of this family (Danforth et al. 2002). Thus, the inconsistent results for the Halictidae and Bombus/Eulaema groups may be related to a change in species composition from one year to another. The low number of individuals observed from these groups compared to the other groups may also have impaired the statistical power of the analyses. The low abundance observed for the Halictidae and Bombus/Eulaema groups may also be related to the generally fragmented landscape we sampled. Therefore, it becomes important to conduct future studies for these groups, especially if it is possible to establish the relationship between group identity and their ecological attributes more precisely.

There was no relationship between abundance of bee groups and the distance from the fragment in the two studied years. A likely explanation for the absence of relationship could be that the distances between native vegetation and tomato fields were small in this study. This is because the fields are located near streams (due to the need for irrigation) that are surrounded by native vegetation. A meta-analysis, involving 16 fields on five continents, showed that the rate of native pollinator visits 
Fig. 4 Standardized coefficient of the effect of each variable on the abundance of bees in the selected models for each group. a-e Open circles correspond to 2010 and filled circles to 2011. Horizonta lines correspond to the confidence interval of 1.96 $\times$ SE. Proportion of native vegetation (Prop.), relative to the largest patch size (rLPS) and observation time (Obsv. time). Positive coefficients represent positive effects of the predictors on bee abundance
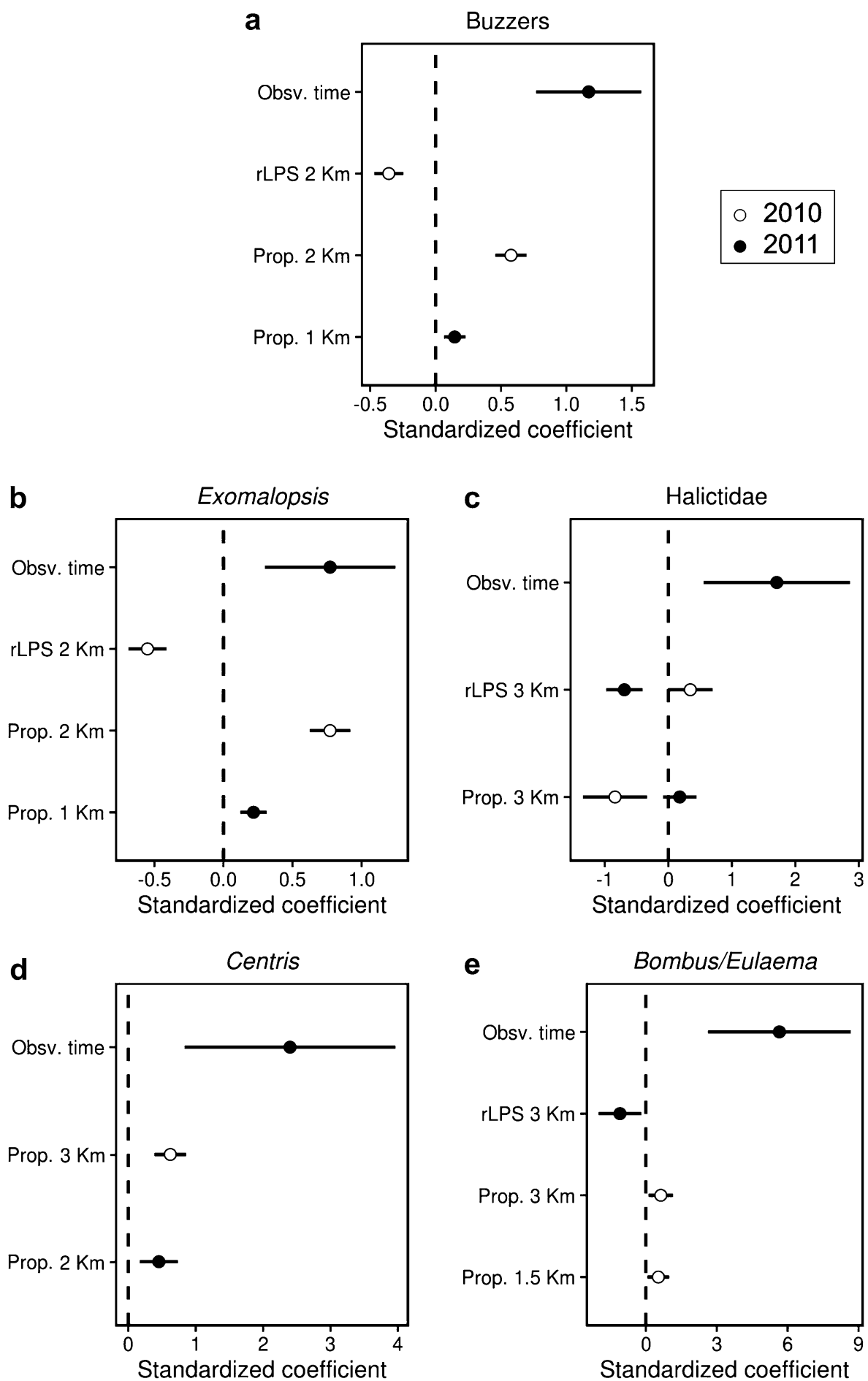

halved at a distance of $0.6 \mathrm{~km}$ (Ricketts et al. 2008). In this study, the average distance of natural areas to tomato fields was less than $0.2 \mathrm{~km}$. Another explanation is that the species present in this study are unresponsive to the distance from the native vegetation at such small scales. Studies show that certain combinations of species traits, such as body size, degree of sociability, and type of nesting substrate can influence the response regarding the distance between fragments (Klein et al. 2003a, b; Ricketts et al. 2008; Jauker et al. 2013).

The influence of landscape context on the abundance and diversity of native bees in an agroecosystem has not been well investigated in the tropical regions. However, this subject is extremely important for planning landscape management to improve bee conservation, ecosystem services, and food production. The results of the present work 
Table 5 Effect of the distance of the closest remaining native vegetation to the tomato crops on the abundance of each bee group from tomato flowers in 10 crops in 2010 and in 14 crops in 2011 in the state of Goiás. Small variance values of the year random effect indicate that the responses were similar for both years

\begin{tabular}{llll}
\hline Groups & $\begin{array}{l}\text { Distance } \\
\mathrm{t} \text { value }\end{array}$ & $\mathrm{p}$ & Year random effect \\
\hline Buzzers & 1.394 & 0.370 & $<0.001$ \\
Exomalopsis & 1.290 & 0.410 & $<0.001$ \\
Halictidae & 0.173 & 0.865 & $<0.001$ \\
Centris & 0.924 & 0.464 & $<0.001$ \\
Bombus/Eulaema & 1.690 & 0.255 & $<0.001$ \\
\hline
\end{tabular}

reinforce the need for maintaining natural habitats, even if fragmented, around field areas for the maintenance of tomato pollinator assemblage. Tomato fields provide only pollen as a food resource for their pollinators, which is restricted to a few months of the year. Therefore, bees necessarily depend on additional resources for their diet and nesting sites, which must be obtained from other sources that may occur in native areas. This study shows the importance of considering the effects that landscape context has on pollinator abundance for an important crop in Brazil and highlights the requirement of multiple scale analysis for detecting these effects on the assemblage of local pollinators (Steffan-Dewenter et al. 2002; Taki et al. 2010).

Acknowledgements We would like to thank Bárbara A. Ribeiro Bergamini, Gisele L. Moreira, and Joicy M. Morais for helping with data collection, and to all the farmers who permitted access to their properties. The Conselho Nacional de Desenvolvimento Científico e Tecnológico - CNPq (National Council for Scientific and Technological Development), FAO (Food and Agriculture Organization), FUNBIO (Brazilian Fund for Biodiversity), and the Brazilian Environment Ministry (MMA) provided funding for this study. Marcos A. Elias was supported by a CNPq scholarship. Leonardo L.Bergamini was supported by a CAPES scholarship.

\section{References}

Aizen MA, Feinsinger P (1994) Habitat fragmentation, native insect pollinators, and feral honey bees in Argentine "Chaco Serrano". Ecol Appl 4:378-392

Allen-Wardell G, Bernhardt P, Bitner R, Burquez A, Buchmann $\mathrm{S}$, Cane J, Cox P, Dalton V, Feinsinger P, Ingram M, Inouye D, Jones C, Kennedy K, Kevan P, Koopowitz H, Medellin R, Medellin-Morales S, Nabhan G, Pavlik B, Tepedino V, Torchio P, Walker S (1998) The potential consequences of pollinator declines on the conservation of biodiversity and stability of food crop yields. Conserv Biol 12: 8-17

Bartón K (2015) MuMIn: Multi-Model Inference. R package version.1.15.1.<http://CRAN.R-project.org/package=MuMIn> Accessed 5 Nov 2015

Bascompte J, Sole R (1996) Habitat fragmentation and extinction thresholds in spatially explicit models. J Animal Ecol $65: 465-473$
Bates D, Maechler M, Bolker B, Walker S (2015) Fitting linear mixed-effects models using lme4. J Stat Softw 67:1-48

Benjamin FE, Reilly JR, Winfree R (2014) Pollinator body size mediates the scale at which land use drives crop pollination services. J Appl Ecol 51:440-449. doi:10.1111/1365-2664.12198

Bivand R, Lewin-Koh N (2015) Maptools: Tools for Reading and Handling Spatial Objects. R Package Version 0.8-36. http:// CRAN.R-project.org/package $=$ maptools. Accessed 5 Nov 2015

Bivand R, Keitt T, Rowlingson B (2015) Rgdal: bindings for the geospatial data abstraction library. R Package Version 1.0-4. http://CRAN.R-project.org/package=rgdal. Accessed 5 Nov 2015

Boreux V, Krishnan S, Cheppudira K, Ghazoul J (2013) Impact of forest fragments on bee visits and fruit set in rain-fed and irrigated coffee agro-forests. Agricult Ecoss Environ 172: 42-48. doi:10.1016/j.agee.2012.05.003

Brosi BJ (2009) The effects of forest fragmentation on euglossine bee communities (Hymenoptera: Apidae: Euglossini). Biol Conserv 142:414-423. doi:10.1111/j.1365-2664.2007.01412.x

Burnham KP, Anderson DR (2002) Model selection and multimodel inference: a practical information-theoretic approach. Springer, New York

Danforth BN (2002) Evolution of sociality in a primitively eusocial lineage of bees. Proc Natl Acad Sci USA 99:286-290

De Marco P, Coelho FM (2004) Services performed by the ecosystem: forest remnants influence agricultural cultures pollination and production. Biodiv Conserv 13:1245-1255

De Palma A, Kuhlmann M, Roberts SPM., Potts SG, Börgre L, Hudson L et al (2015) Ecological traits affect the sensitivity of bees to land-use pressures in European agricultural landscapes. J Appl Ecol 52:1567-1577. doi:10.1111/1365-2664.12524

Deprá MS, Delaqua GCG, Freitas L, Gaglianone MC (2014) Pollination deficit in open-field tomato crops (Solanum lycopersicum L., Solanaceae) in Rio de Janeiro state, Southeast Brazil. J Poll Ecol $12: 1-8$

Fahrig L (2003) Effects of habitat fragmentation on biodiversity. Annu Rev Ecol Evol Syst 34:487-515. doi:10.1146/annurev. ecolsys.34.011802.132419

Fontes P, Silva D (2002) Produção de tomate de mesa. Aprenda Fácil Editora, Viçosa, BR.

Fürst MA, McMahon DP, Osborne JL, Paxton RJ, Brown MJF (2014) Disease associations between honeybees and bumblebees as a threat to wild pollinators. Nature 506:364-366. doi:10.1038/ nature 12977

Gathmann A, Tscharntke T (2002) Foraging ranges of solitary bees. J Animal Ecol 71:757-764

Goulson D, Hanley ME, Darvill B, Ellis J, Knight ME (2005) Causes of rarity in bumblebees. Biol Conserv 122:1-8

Goulson D, Nicholls E, Botías C, Rotheray EL (2015) Bee declines driven by combined stress from parasites, pesticides, and lack of flowers. Science 347(6229):1255957. doi:10.1126/ science. 1255957

Greenleaf SS, Kremen C (2006) Wild bee species increase tomato production and respond differently to surrounding land use in Northern California. Biol Conserv 3:81-87. doi:10.1016/j. biocon.2006.05.025

Greenleaf SS, Williams NM, Winfree R, Kremen C (2007) Bee foraging ranges and their relationship to body size. Oecologia 153:589-596. doi:10.1007/s00442-007-0752-9

Harris FL, Johnson S (2004) The consequences of habitat fragmentation for plant-pollinator mutualisms. Int J Trop Ins Sci 24:29-43. doi:10.1079/IJT20049

Heinzl H, Mittlböck M (2003) Pseudo R-squared measures for Poisson regression models with over- or underdispersion. Comput Stat Data Anal 44:253-271 
Hijmans RJ (2015) Raster: Geographic data analysis and modeling. R Package Version 2.4-15. http://CRAN.R-project.org/ package $=$ raster Accessed 10 Nov 2015

IBGE (2015) Sistema IBGE de Recuperação Automática - SIDRA. http://www.sidra.gov.br/bda/tabela/listabl.asp\&gt;. Accessed 12 June 2015

IPBES (2016) Summary for policymakers of the assessment report of the Intergovernmental Science-Policy Platform on Biodiversity and Ecosystem Services on pollinators, pollination and food production. Potts SG, Imperatriz-Fonseca VL, Ngo HT, Biesmeijer JC, Breeze TD, Dicks LV, Garibaldi LA, Hill R, Settele J, Vanbergen AJ, Aizen MA, Cunningham SA, Eardley C, Freitas BM, Gallai N, Kevan PG, Kovács-Hostyánszki A, Kwapong PK, Li J, Li X, Martins DJ, Nates-Parra G, Pettis JS, Rader R, Viana BF (eds.). Secretariat of the Intergovernmental Science-Policy Platform on Biodiversity and Ecosystem Services. IPBES, Bonny

Jauker B, Krauss J, Jauker F, Steffan-Dewenter I (2013) Linking life history traits to pollinator loss in fragmented calcareous grasslands. Landsc Ecol 28:107-120. doi:10.1007/s10980-012-9820-6

Kearns CA, Inouye DW, Waser NM (1998) Endangered mutualisms: the conservation of plant-pollinator interactions. Ann Rev Ecol Syst 29:83-112

Kennedy CM, Lonsdorf E, Neel MC, Williams NM, Ricketts TH, Winfree R, Bommarco R, Brittain C, Burley AL, Cariveau D, Carvalheiro LG, Chacoff NP et al (2013) A global quantitative synthesis of local and landscape effects on wild bee pollinators in agroecosystems. Ecol Lett 16:584-599. doi:10.1111/ele.12082

Kevan PG (1977) Blueberry crops in Nova Scotia and New Brunswick - Pesticides and crop reductions. Can. J Agric Econ 25:61-64

Kleijn D, Winfree R, Bartomeus I, Carvalheiro LG, Henry M, Isaacs R, Klein A-M, Kremen C, M'Gonigle LK, Rader R, Ricketts TH, Williams NM, Adamson NL, Ascher JS, Báldi A, Batáry P, Benjamin F, Biesmeijer JC, Blitzer EJ, Bommarco R, Brand MR, Bretagnolle V, Button L, Cariveau DP, Chifflet R, Colville JF, Danforth BN, Elle E, Garratt MPD, Herzog F, Holzschuh A, Howlett BG, Jauker F, Jha S, Knop E, Krewenka KM, Le Féon V, Mandelik Y, May EA, Park MG, Pisanty G, Reemer M, Riedinger V, Rollin O, Rundlöf M, Sardinas HS, Scheper J, Sciligo AR, Smith HG, Steffan-Dewenter I, Thorp R, Tscharntke T, Verhulst J, Viana BF, Vaissière BE, Veldtman R, Westphal C, Potts SG (2015) Delivery of crop pollination services is an insufficient argument for wild pollinator conservation. Nat Commun 6: 7414. doi: $10.1038 /$ ncomms 8414

Klein AM, Steffan-Dewenter I, Tscharntke T (2003a) Fruit set of highland coffee increases with the diversity of pollinating bees. Proc Royal Soc B-Biol Sci 270:955-961. doi:10.1098/ rspb.2002.2306

Klein AM, Steffan-Dewenter I, Tscharntke T (2003b) Pollination of Coffea canephora in relation to local and regional agroforestry management. J App Ecol 40:837-845

Klein AM, Vaissiere BE, Cane JH, Steffan-Dewenter I, Cunningham SA, Kremen C, Tscharntke T (2007) Importance of pollinators in changing landscapes for world crops. Proc Royal Soc B 274:303-313. doi:10.1098/rspb.2006.3721

Knight ME, Martin AP, Bishop S, Osborne JL, Hale RJ, Sanderson RA, Goulson D (2005) An interspecific comparison of foraging range and nest density of four bumblebee (Bombus) species. Mol Ecol 14:1811-1820. doi:10.1111/j.1365-294X.2005.02540.x

Kruess A, Tscharntke T (1994) Habitat fragmentation, species loss, and biological control. Science 264:1581-1584

Landaverde-González P, Quezada-Euán JJG, Theodorou P, Murray TE, Husemann M, Ayala R, Moo-Valle H, Vandame R, Paxton RJ (2017) Sweat bees on hot chillies: provision of pollination services by native bees in traditional slash-and-burn agriculture in the Yucatán Peninsula of tropical Mexico. J App Ecol. doi:10.1111/1365-2664.12860
Lepais O, Darvill B, O'Connor S, Osborne JL, Sanderson RA, Cussans J, Goffe L, Goulson D (2010) Estimation of bumblebee queen dispersal distances using sibship reconstruction method. Mol Ecol 19: 819-831. doi:10.1111/j.1365-294X.2009.04500.x

McGregor SE (1976) Insect pollination of cultivated crop plants. Agricultural Research Service, United States Department of Agriculture, Washington DC

McKenzie AJ, Emery SB, Franks JR, Whittingham MJ (2013) Landscape-scale conservation: collaborative agri-environment schemes could benefit both biodiversity and ecosystem services, but will farmers be willing to participate? J App Ecol 50:12741280. doi:10.1111/1365-2664.12122

Michener CD (2001) The bees of the world. Johns Hopkins University Press, Baltimore

MMA/IBAMA (2011a) Monitoramento do desmatamento nos biomas brasileiros por Satélite: Monitoramento do bioma Cerrado: 2008-2009. Brasília/DF: Centro de Sensoriamento RemotoCSR/IBAMA. http://siscom.ibama.gov.br/monitorabiomas/cerrado/RELATORIO_CERRADO_2008-2009.pdf. Accessed 18 Aug 2014

MMA/IBAMA (2011b) Monitoramento do desmatamento nos biomas brasileiros por Satélite. Monitoramento do bioma Cerrado: 2009-2010. Brasília/DF: Centro de Sensoriamento RemotoCSR/IBAMA. http://siscom.ibama.gov.br/monitorabiomas/cerrado/RELATORIO\%20FINAL_CERRADO_2010.pdf. Accessed 18 Aug 2014

MMA/IBAMA/PNUD (2009) Relatório Técnico de Monitoramento do Desmatamento no Bioma Cerrado, 2002 a 2008: Dados Revisados. Brasília/DF: Centro de Sensoriamento RemotoCSR/IBAMA, 2009, p 69 http://siscom.ibama.gov.br/monitorabiomas/cerrado/Relatorio\%20tecnico_Monitoramento $\% 20$ Desmate_Bioma\%20Cerrado_CSR_REV.pdf. Accessed 18 Aug 2014

Montoya D, Albuquerque FS, Rueda M, Rodríguez MA (2010) Species response patterns to habitat fragmentation: do trees support the extinction threshold hypothesis? Oikos 119:1335-1343. doi:10.1111/j.1600-0706.2010.18280.x

Morandin LA, Winston ML, Abbott VA, Franklin MT (2007) Can pastureland increase wild bee abundance in agriculturally intense areas?. Basic Appl Ecol 8:117-124. doi:10.1016/j. baae.2006.06.003

Nemésio A, Silveira FA (2010) Forest fragments with larger core areas better sustain diverse orchid bee faunas (Hymenoptera: Apidae: Euglossina). Neotrop Entomol 39:555-561. doi:10.1590/S1519-566X2010000400014

Nunes-Silva P, Hrncir M, Imperatriz-Fonseca, VL (2010) A polinização por vibração. Oecol Aust 14: 140-151. doi:10.4257/ oeco.2010.1401.07

Oliveira PE, Gibbs PE (2002) Pollination and reproductive biology in cerrado plant communities. In: Oliveira PS, Marquis RJ (eds) The cerrados of Brazil: ecology and natural history of a Neotropical Savanna. Columbia University Press, New York, pp 329-347

Oliveira-Filho AT, Ratter JA (2002) Vegetation physiognomies and woody flora of the cerrado biome. In: Oliveira PS, Marquis RJ (eds) The cerrados of Brazil: ecology and natural history of a Neotropical Savanna. Columbia University Press, New York, pp 91-120

Ollerton J, Winfree, R Tarrant S (2011) How many flowering plants are pollinated by animals? Oikos 120:321-326. doi:10.1111/j.1600-0706.2010.18644.x

Osborne JL, Clark SJ, Morris RJ, Williams IH, Riley JR, Smith AD, Reynolds DR, Edwards AS (1999) A landscape-scale study of bumble bee foraging range and constancy, using harmonic radar. J App Ecol 36:519-533. doi:10.1046/j.1365-2664.1999.00428.x

Pinto NS, Silva DP, Rodrigues JG, De Marco P Jr (2015) The size but not the symmetry of the wings of Eulaema nigrita Lepeletier 
(Apidae: Euglossini) is affected by human-disturbed landscapes in the Brazilian cerrado savanna. Neotrop Entom 44: 439-447. doi:10.1007/s13744-015-0316-3

Potts SG, Biesmeijer JC, Kremen C, Neumann, P Schweiger O, Kunin WE (2010) Global pollinator declines: trends, impacts and drivers. Trends Eco Evol 25:345-353. doi:10.1016/j. tree.2010.01.007

Potts S, Biesmeijer K, Bommarco R, Breeze T, Carvalheiro L, Franzén M, González-Varo JP, Holzschuh A, Kleijn D, Klein AM, Kunin B, Lecocq T, Lundin O, Michez D, Neumann P, Nieto A, Penev L, Rasmont P, Ratamäki O, Riedinger V, Roberts S, Rundlöf M, Scheper J, Sørensen P, Steffan-Dewenter I, Stoev P, Vilà M, Schweiger O (2015) Status and trends of European Pollinators. Pensoft Publishers, Sofia

Powell AH, Powell GVN (1987) Population dynamics of male euglossine bees in Amazonian forest fragments. Biotropica 19:176-179

R Development Core Team (2015) R: a language and environment for statistical computing. R Foundation for Statistical Computing, Vienna

Ricketts TH (2004) Tropical forest fragments enhance pollinator activity in nearby coffee crops. Conserv Biol 18: 1262-1271. doi:10.1111/j.1523-1739.2004.00227.x

Ricketts TH, Daily GC, Ehrlich PR, Michener CD (2004) Economic value of tropical forest to coffee production. Proc Natl Acad Sci USA 101: 12579-12582. doi:10.1073/pnas.0405147101

Ricketts TH, Regetz J, Steffan-Dewenter I, Cunningham SA, Kremen C, Bogdanski A, Gemmill-Herren B, Greenleaf SS, Klein MA, Mayfield MM, Morandin LA, Ochieng A, Potts SG, Viana BF (2008) Landscape effects on crop pollination services: are there general patterns? Ecol Lett 11:499-515. doi:10.1111/j.1461-0248.2008.01157.x

Rocha GF, Ferreira LG, Ferreira NC, Ferreira ME (2010) Detecção de Desmatamentos no Bioma Cerrado entre 2002 e 2009: Padrões, Tendências e Impactos. R Bras Cart 63:341-349

Romero MJ, Quezada-Euan JJ (2013) Pollinators in biofuel agricultural systems: the diversity and performance of bees (Hymenoptera: Apoidea) on Jatropha curcas in Mexico. Apidologie 44:419-429. doi:10.1007/s13592-013-0193-x

Rösch V, Tscharntke T, Scherber C, Batáry, P (2013) Landscape composition, connectivity and fragment size drive effects of grassland fragmentation on insect communities. J Appl Ecol 50:387-394.

Roubik DW (2001) Ups and downs in pollinator populations: When is there a decline?. Conserv Ecol 5:2

Rueda M, Hawkins BA, Morales-Castilha I, Vidanes RM, Ferrero M, Rodríguez MÁ (2013) Does fragmentation increase extinction thresholds? A European-wide test with seven forest birds. Global Ecol Biogeogr 22:1282-1292. doi:10.1111/geb.12079

Silva-Neto CM, Gomes FL, Gonçalves BB, Bergamini LL, Bergamini BAR, Elias MAS, Franceschinelli EV (2013) Native bees pollinate tomato flowers and increase fruit production. J Pollinat Ecol $11: 41-45$
Silva-Neto CM, Bergamini LL, Elias MAS, Moreira GL, Morais JM, Bergamini BAR, Franceschinelli EV (2016) High species richness of native pollinators in Brazilian tomato crops. Braz J Biol. doi:10.1590/1519-6984.17515

Steffan-Dewenter I (2003) Importance of habitat area and landscape context for species richness of bees and wasps in fragmented orchard meadows. Conserv Biol 17:1036-1044. doi:10.1046/j.1523-1739.2003.01575.x

Steffan-Dewenter I, Kuhn A (2003) Honeybee foraging in differentially structured landscapes. Proc R Soc B 270:569-575. doi:10.1098/rspb.2002.2292

Steffan-Dewenter I, Münzenberg U, Bürger C, Thies C, Tscharntke $\mathrm{T}$ (2002) Scale-dependant effects of landscape context on three pollinator guilds. Ecology 83:1421-1432

Taki H, Okabe K, Yamaura Y, Matsura T, Sueyoshi M, Makino S, Maeto K (2010) Effects of landscape metrics on Apis and nonApis pollinators and seed set in common buckwheat. Basic Appl Ecol 11:594-602. doi:10.1016/j.baae.2010.08.004

Tonhasca A Jr, Albuquerque GS, Blackmer JL (2003) Dispersal of euglossine bees between fragments of the Brazilian Atlantic Forest. J Trop Ecol 19:99-102

Tscharntke T, Steffan-Dewenter I, Kruess A, Thies C (2002) Contribution of small habitat fragments to conservation of insect communities of grassland-cropland landscapes. Ecol Appl 12:354 363. doi:10.1890/1051-0761(2002)012[0354:COSHFT]2.0.CO;2

Viana BF, Boscolo D, Neto EM, Lopes LE, Lopes AV, Ferreira PA, Pigozzo CM, Primo LM (2012) How well do we understand landscape effects on pollinators and pollination service?. J Pollinat Ecol 7:31-41

Waibel L (1948) Vegetation and land use in the Planalto Central of Brazil. Geogr Rev 38:529-554

Walther-Hellwig K, Frankl R (2000) Foraging habitats and foraging distances of bumblebees, Bombus spp. (Hym., Apidae), in an agricultural landscape. J Appl Entomol 124:299-306. doi:10.1046/j.1439-0418.2000.00484.x

Whitehorn PR, O'Connor S, Wackers FL, Goulson D (2012) Neonicotinoid pesticide reduces bumble bee colony growth and queen production. Science 336:351-352. doi:10.1126/science.1215025

Williams NM, Minckley RL, Silveira FA (2001) Variation in native bee faunas and its implications for detecting community changes. Conserv Ecol 5:7

Winfree R (2013) Global change, biodiversity, and ecosystem services: What can we learn from studies of pollination? Basic Appl Ecol 14:453-460. doi:10.1016/j.baae.2013.07.004

Winfree R, Kremen C (2009) Are ecosystem services stabilized by differences among species? A test using crop pollination. Proc $\mathrm{R}$ Soc B 276:229-237. doi:10.1098/rspb.2008.0709

Zuur A, Ieno EN, Walker N, Saveliev AA, Simth GM (2009) Mixed effects models and extensions in ecology with R. Springer, New York 